\title{
GenEthics and religion
}

\author{
Editors: Georg Pfleiderer, Gabriella Brahier, Basel, Switzerland; Klaus Lindpaintner, \\ Newark, USA. 154 pages, hard cover, 2010, Karger, Basel, Switzerland. ISBN 97838055 \\ 89734
}

\author{
Martina C. Cornel
}

Received: 18 September 2010 / Accepted: 21 September 2010 /Published online: 2 October 2010

(C) The Author(s) 2010. This article is published with open access at Springerlink.com

Based on the symposium 'GenEthics and Religion' held in Basel, Switzerland, in May 2008, this volume examines the role religion can play in establishing ethical guidelines to protect human life in the face of rapid advances in biology and especially gene technology. Book contributions were written by philosophers, theologians, human geneticists and several bioethicists representing the Christian, Jewish, Islamic and Buddhist perspectives.

Progress in modern genetics challenges medical ethics. Religion and science are by no means totally separate from each other, although a certain distance has developed between theologians and scientists. Many theologians, however, show a distinctive interest in natural sciences, such as the Augustinian monk Gregor Mendel, the founder of modern genetics. A scientist's daily work involves a profound and close study of creation which permits him a very direct insight into its 'wonders' and helps him develop great respect for its power. Interdisciplinary collaboration can be especially helpful in formulating guidelines for complex but concrete ethical issues. In medical genetics in particular, the counselling offered to patients often does not focus on scientific or medical aspects of a hereditary

\footnotetext{
M. C. Cornel $(\bowtie)$

VU University Medical Centre, Clinical Genetics/EMGO Institute for Health and Care Research,

Amsterdam, the Netherlands

e-mail: mc.cornel@vumc.nl

M. C. Cornel

Centre for Society and Genomics,

Nijmegen, the Netherlands
}

disease but rather on its ethical and psychosocial implications. Whilst basic principles of bioethics, such as autonomy, beneficence, non-maleficence and justice, as formulated by Beauchamp and Childress, play an important role in genetic health care, it is especially the interdisciplinary debate on practical questions related to prenatal diagnosis, pre-implantation diagnostics, genetic screening or synthetic biology that is needed to generate guidance in these new and challenging issues. This volume contributes to this interdisciplinary debate.

The book covers a wide range of topics and perspectives. I selected a few that caught my attention. The terminology used by journalists and scientists is full of metaphors. Using descriptions as the genetic blueprint for human beings may suggest that DNA contains the instructions for the body on how to develop, how to stay alive, how to grow, etc. Nowadays, the genetic determinism implied in the metaphor is not supported by most scientists, so a new metaphor is suggested by Rehmann-Sutter: systems. In complex molecular systems, mutual influences exist. Genes alone are not sufficient for the complete description of developmental pathways. Rather than considering nature responsible for writing our book of life, individual persons have a responsibility to know about their risk and possible precautions.

The Jewish perspective on genetics shows a striking paradox. No religious group has been more victimized by genetics than Jews, under the Nazi regime. Yet, no single religious group has been more receptive to genetic medicine than Jews, including prenatal testing, in vitro fertilization, pre-implantation genetic diagnosis, preconceptional screening and stem cells. At its roots, Judaism is a 
tradition that sees human beings as 'co-creators' with God in creation and that does not exhibit a fear that human beings will use technology to 'play God'.

The Muslim perspective is described by Siti Nurani Mohamed Nor. As Asia is the hub of biotechnological superpowers, Nor's chapter is focussing on biotechnology, especially human embryo research. According to her, there is a plurality of views regarding the beginning of life. Lawmakers consider every action in light of the choice of the lesser of two evils, in this context foregoing the potential of gene technology vs. infringements of the objectives of Islamic law, which are defined by five basic human interests: life, religion, property, intellect and family lineage. On the beginning of human life, there is a general consensus that there is potential life in early embryos and they must be treated with caution. The intention to eliminate diseases may be justified in actions that may bring about the possibility of embryo destruction. This sometimes is interpreted to be the lesser of two evils. She further proposes a reasoned and sustained deliberation on the ethics of stem cell research, including biotechnological as well as philosophical and theological perspectives.

Buddhism, according to Pinit Ratanakul, in principle has no difficulty to cope with new scientific achievements such as genetics and biotechnology. Advances in human genetic research and its applications in medical practices such as diagnosis, treatment and prevention of genetic diseases are of great promise and bring hopes for the cure of incurable diseases which many people are afflicted with. The core of Buddhist ethics is compassion, involving beneficence, nonmaleficence and other forms of altruism. Buddhism sees the Human Genome Project and genetic engineering technologies as important ways to relieve human suffering and promote human well-being. The reason for this liberal attitude of Buddhist ethics towards genetics is to be found in a general affinity of Buddhism and science as both see the need for the verification of truth by reason and experience. A less liberal attitude applies to the beginning of life. An embryo is human and thus possesses human dignity and human rights at the time of conception. In Buddhism, persons are interdependent. Germline cell therapy for instance is ethically questionable due to its potentially negative effects on humanity.

Five parts and 13 chapters contain a diversity of issues for debate. In pluralistic societies and within several religious groups, discussions on how to balance pros and cons of genetics and biotechnology are taking place. The book presents a kaleidoscope of these perspectives and shows that the challenges of the rapid progress of modern gene technology demand that religious ethics engages in new ideas and unorthodox ethical reflections.

Open Access This article is distributed under the terms of the Creative Commons Attribution Noncommercial License which permits any noncommercial use, distribution, and reproduction in any medium, provided the original author(s) and source are credited. 